\title{
RELATIONSHIP OF SELECTED ANTHROPOMETRIC AND LINEAR KINEMATICAL VARIABLES WITH THE PERFORMANCE OF TOE-TOUCH SKILL IN KABADDI
}

\author{
Jasvir Ram ${ }^{1 \mathrm{ABCDE}}$, Joseph Singh ${ }^{1 \mathrm{ADE}}$ \\ ${ }^{1}$ Lakshmibai National Institute of Physical Educationi \\ Authors' Contribution: A - Study design; B - Data collection; C - Statistical analysis; D - Manuscript Preparation; E - Funds Collection
}

Corresponding Author: Jasvir Ram, E-mail: jasvirram9@gmail.com

Accepted for Publication: October 16, 2021

Published: December 25, 2021

DOI: 10.17309/tmfv.2021.4.03

\begin{abstract}
The purpose of this study was to find out the relationship of selected anthropometric and linear kinematical variables with the performance of toe-touch skill among male kabaddi players (raiders).

Materials and Methods. One hundred male raiders were selected for this study. The age of the subjects ranged between 18 to 25 years. Selected anthropometric variables: foot length, upper leg length, lower leg length, thigh girth and calf girth were measured by standardized equipment. Selected linear kinematical variables were measured by digital software "Kinovea version-0.9.3" The toe-touch skill performed by raiders was assessed by three experts rating. The inter-rater reliability of the scores awarded by the experts to the subjects was tested by Cohen's Kappa test and Kappa coefficient was found significant.

Results. Spearman's rank correlation revealed that there was significant correlation in case of thigh girth ( $\mathrm{rs}=0.230$, $\mathrm{p}=0.022)$, distance $(\mathrm{rs}=0.245, \mathrm{p}=0.014)$ and center of gravity $(\mathrm{rs}=-0.270, \mathrm{p}=0.007)$ variables, and there was not significant correlation in case of upper leg length $(r s=0.048, p=0.634)$, lower leg length ( $r s=-0.90, p=0.373)$, calf girth ( $\mathrm{rs}=0.093, \mathrm{p}=0.355)$, foot length $(\mathrm{rs}=-0.17, \mathrm{p}=0.863)$ and time $(\mathrm{rs}=-0.006, \mathrm{p}=0.952)$ variables with the performance of toe-touch skill in kabaddi.

Conclusion. The study concludes that thigh girth and distance positively and center of gravity negatively contributes to the performance of toe-touch skill in male kabaddi players.

Keywords: kabaddi, raider, skill, anthropometrical variables, linear kinematics.
\end{abstract}

\section{Introduction}

Kabaddi is combative team game, which is played all over India. In terms of success, this game is also getting a good status in Asian sports (Jadhav, 2012). It is also known as the "game of the masses," since spectators totally involve themselves and give a great deal of encouragement to the players (Dey, Khanna \& Batra, 1993; Arshaq \& Martin, 2018). This sport requires a high amount of physical fitness in the players to execute offensive push, falls, turns, sudden change of direction holding, bending, jumping, leg and hand touch, and maintaining holding and respiration. An athlete of this sport should have physical stamina, agility, individual proficiency, neuromuscular coordination, mental toughness with the presence of mind on both attackers and defenders (Nataraj \& Chandrakumar, 2008). There are many offensive and defensive skills in kabaddi which are used by defenders and raiders.

(C) Ram, J., \& Singh, J., 2021.
Kabaddi is perhaps the only combative sport in which attack is an individual attempt while defense is a group effort (Patel, Pandey, Saxena, \& Kalyanpur, 2011). Toe-touch is an offensive skill which is used by the raider to touch the opponent during raid. While performing this skill, the raider requires to extend his leg suddenly towards the anti. He extends all the joints (knee and ankle) in order to cover more distance and touch with the inner portion of the toe (Itoo \& Jain, 2020).

Sports performance is based on a complex and intricate diversity of numerous factors such as physical, physiological and anthropometric, variety mixture of all inborn qualities, represent most important and fundamental criteria of athletes' performance, which play vital role in success in a specific sport and reach to high level of performance (Bosco, Komi, Tihanyi, Fekete \& Apor, 1983; Campo, Vaeyens, Philippaerts, Redondo, De-Benito \& Cuadrado, 2009; Gaurav, Singh \& Singh, 2011). Talent identification and its improvement have emerged as an important region of studies in sports. In prediction consequences are anticipated be- 
forehand. Usually, the expected effects aren't risk of guesses, however are based upon some known statistics of courting or cautiously conceived beliefs (Clarke, Harrison \& ClarkeDavid, 1972).

Kinanthropometry is the measurement of body size and proportions. The measurements encompass frame weight, height, circumferences, skin fold thickness, bony widths and lengths. At present, sportsman for superior performance in any sports activities is chosen on the basis of bodily shape and frame length (Heyward, 2006). Anthropometric dimensions and morphological characteristics of athletes play a vital role to decide the achievement, especially in sports activities. In diverse ways, information of anthropometric traits is important to establish their importance for the fulfilment in competitive sport (Keogh, 1999; Viswanathan \& Chandrasekaran, 2011; Wilmore \& Costill, 2005).

According to Hatze, "Biomechanics is the science which studies structure and function of Biological systems using the knowledge and methods of mechanics". Biomechanics can be stated that the cumulative function of skeletal, Muscular, and Joints to execute any task. Proper understanding of biomechanics has the greatest application in injury prevention, rehabilitation along with the mastery over the technique (Hatze, 1981).

It is very essential to understand about the application of physics to games and sports, Exercises Such as Speed, distance, displacement, resistance, Acceleration, forces, resistance, momentum and friction which play vital role in sports. The general role of biomechanics is to understand the cause effect relationship of biomechanical variables and performance. Video has much application in the field of sports and science. Athlete and coaches use medium more and more to measure the correct technique. Video analysis software has many applications in biomechanical research (Bartlett, 2007).

Various studies have been conducted by the researchers to find out the relationship of anthropometric variables with the playing ability of kabaddi players (Devaraju \& Needhiraja, 2012; Johnson, 2016; Pandey \& Sardar, 2016). But there is not a single study available in a literature which describes the relationship of anthropometric variables with a particular skill performance on kabaddi. There is a very smaller number of biomechanical studies in kabaddi (Ram, 2019ab). Hence, the purpose of this study was to find out the relationship of selected anthropometric and linear kinematical variables with the toe-touch skill performance (TTSP).

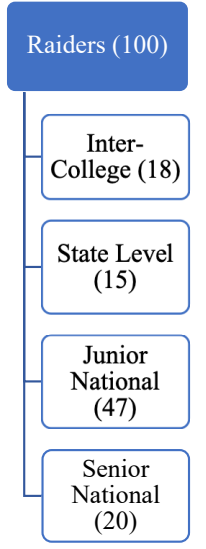

Fig. 1. Description of sampling plan

\section{Materials and Methods}

\section{Study participants}

One hundred male raiders were selected for this study by purposive sampling technique who at least participated in inter-college level competition. The age of the subjects was ranged between 18-25 years. All the subjects had knowledge and training experience in kabaddi.

The subjects were selected from various kabaddi academies of four states: Punjab, Himachal Pradesh, Haryana and Uttarakhand, and one union territory: Chandigarh. A prior permission was taken from coaches of kabaddi academies before data collection.

Total 8 variables ( 5 anthropometrical +3 linear kinematical variables were selected in this study (Table 1$)$. This study was the part of $\mathrm{PhD}$ topic which was approved by DRC (Departmental Research Committee).

\section{Procedure}

All the participants were informed in details about research protocol and the basic characteristics of the study. No special motivation technique was used to motivate the players before data collection. All the participants executed the same protocol under the same circumstances and were guided by researcher. The measurements of foot length $(\mathrm{cm})$, upper leg length $(\mathrm{cm})$ and lower leg length $(\mathrm{cm})$ were taken with a standardized equipment Lafayette Bone Caliper (Model 01293). The measurements of thigh girth $(\mathrm{cm})$ and calf girth $(\mathrm{cm})$ were taken with a standardized equipment Gulick Anthropometric tape (Table 1) (Norton \& Olds, 2006).

To measure the performance of the toe-touch skill of raiders, instructions were given to raiders that they have to raid in opponents side and perform a toe-touch skill. Appropriate time was given to raiders and defenders for general and specific warm-up. Match situation was created and raiders were asked to raid. Three raids were given to every raider and best one was considered. Performance of every

Table 1. List of variables

\begin{tabular}{lll}
\hline S.N. & \multicolumn{1}{c}{ Variables } & \multicolumn{1}{c}{ Explanation } \\
\hline 1. & Foot length & A measure of the distance from the heel to the longest toe of the left foot \\
2. & Upper leg length & The distance from the trochanterion to the tibiale laterale \\
3. & Lower leg length & The distance from the tibiale laterale to the sphyrion tibiale \\
4. & Thigh girth & $\begin{array}{l}\text { Measurement taken perpendicular to the long axis of the thigh at the level midway between the } \\
\text { trochanterion and tibiale laterale sites }\end{array}$ \\
5. & Calf girth & The calf girth measurement is a measure of the circumference of the lower leg \\
6. & Time & Time taken to execute toe-touch skill \\
7. & Distance & Distance between both feet during an execution phase of toe-touch skill \\
8. & Center of gravity & Location of the concentrated weight of a raider during an execution phase of toe-touch skill
\end{tabular}


Table 2. Description of selected tools and their measuring units

\begin{tabular}{llll}
\hline S.N. & \multicolumn{1}{c}{ Variable } & \multicolumn{1}{c}{ Tool } & Measuring Unit \\
\hline 1. & Foot Length & Lafayette Bone Caliper (Model 01293) & Centimeter \\
2. & Upper Leg Length & Lafayette Bone Caliper (Model 01293) & Centimeter \\
3. & Lower Leg Length & Lafayette Bone Caliper (Model 01293) & Centimeter \\
4. & Thigh Girth & Gulick Anthropometric tape & Centimeter \\
5. & Calf Girth & Gulick Anthropometric tape & Centimeter \\
6. & Time Taken for execution of the skill & Kinovea Software & Second \\
7. & Distance between both feet during the execution phase of & Kinovea Software & Centimeter \\
8. & skill & & Center of Gravity during the execution phase of skill \\
9. & Toe-Touch Skill Performance & Kinovea Software & Points \\
\hline
\end{tabular}

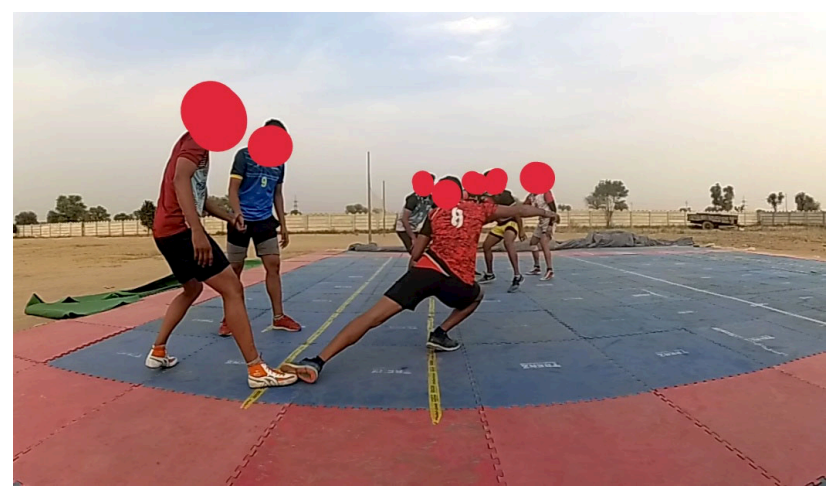

Fig. 2. Subject performing Toe-Touch skill

raid was recorded by Y1-Action Camera with a speed of 240fps (Figure 2).

For the measurement of selected linear kinematical variables, recorded videos of skill performance were analyzed by digital software 'Kinovea version-0.9.3' speed (seconds), distance $(\mathrm{cm})$ and center of gravity $(\mathrm{cm})$ variables were calculated (Gogoi \& Rajpoot, 2019).

After the completion of data collection process, researchers contacted with kabaddi experts and explained them about the purpose of this study and also about their role to give rating to the subjects according to their performance. Rating scale was given to each expert before starting the evaluation process (Table 2 ). The recorded videos of subjects' performances were shown to three experts for rating purpose. All experts were having diploma of coaching in kabaddi and also having participation in national level competitions. The inter-rater reliability of experts was tested by using Cohen's Kappa inter-rater reliability test and Kappa's coefficient was found significant (Kvålseth, 1989). The average of the total scores given by the subjects was taken as final performance score of the subjects.

\section{Statistical Technique}

Descriptive statistics i.e., median, inter-quartile range was calculated. According to the nature of data non-parametric test 'Spearman Rank Correlation' was employed to find out the relationship between TTSP and anthropometric variables with the help of SPSS-software version 23. Level of significance was set at 0.05 (Zar, 2005).
Table 3. Explanation of Rating Scale

\begin{tabular}{ccc}
\hline S.N. & Comment & Score \\
\hline 1. & Very Good & 5 \\
2. & Good & 4 \\
3. & Average & 3 \\
4. & Satisfactory & 2 \\
5. & Poor & 1 \\
\hline
\end{tabular}

\section{Results}

Table 4 shows the median and inter quartile range values of skill performance scores and selected anthropometric variables. Median and inter quartile range values of performance scores, foot length, upper leg length, lower leg length, thigh girth and calf girth variables are 3(1), 25(1.88), $41.50(4.50), 37.50(2.88), 54(6)$ and $36(2.50)$ respectively. It also shows that there is an insignificant relationship of foot length ( $\mathrm{rs}=-0.17, \mathrm{p}=0.863$ ), upper leg length ( $\mathrm{rs}=0.048$, $\mathrm{p}=0.634)$, lower leg length ( $\mathrm{rs}=-0.90, \mathrm{p}=0.373$ ) and calf girth ( $\mathrm{rs}=0.093, \mathrm{p}=0.355)$ with toe-touch skill performance and significant relationship of thigh girth ( $r s=0.230$, $\mathrm{p}=0.022$ ) with toe-touch skill performance.

Table 5 shows the median and inter quartile range values of skill performance scores and selected linear kinematical variables. Median and inter quartile range values of performance scores, time, distance and enter of gravity variables are $3(1), 0.433(0.19), 86.25(24.78)$ and $44.12(14.76)$ respectively. It also shows that there is an insignificant relationship of time variable ( $r s=-0.006, p=0.952$ ) with toe touch skill performance and significant relationship of distance variable ( $\mathrm{rs}=0.245, \mathrm{p}=0.014$ ) with toe-touch skill performance at 0.05 level of significance and center of gravity variable ( $\mathrm{rs}=-0.270, \mathrm{p}=0.007$ ) with toe-touch skill performance at 0.01 level of significance.

\section{Discussion}

There is evidence that anthropometric variables contribute significantly in the playing ability of male kabaddi players (Devaraju \& Needhiraja, 2012). The purpose of this study was to find out the relationship of selected anthropometric and linear kinematical variables with the performance of 
Table 4. The Relationship of selected anthropometric variables with the performance of toe-touch skill

\begin{tabular}{llllll}
\hline S.N. & \multicolumn{1}{c}{ Variable } & Median & IQR & 'r' value & p-value (sig.) \\
\hline 1 & Performance Scores & 3 & 1 & - & - \\
2 & Foot Length & 25 & 1.88 & -0.017 & 0.863 \\
3 & Upper Leg Length & 41.50 & 4.50 & 0.048 & 0.634 \\
4 & Lower Leg Length & 37.50 & 2.88 & -0.090 & 0.373 \\
5 & Thigh Girth & 54 & 6 & 0.230 & $0.022^{\star}$ \\
6 & Calf Girth & 36 & 2.50 & 0.093 & 0.355
\end{tabular}

Note: IQR = Inter Quartile Range; ${ }^{\star}$ Denotes significant relationship at 0.05 level of significance

Table 5. The Relationship of selected linear kinematical variables with the performance of toe-touch skill

\begin{tabular}{llcccc}
\hline S.N. & Variable & Median & IQR & 'r' value & p-value (sig.) \\
\hline 1 & Performance Scores & 3 & 1 & - & - \\
2 & Time & 0.433 & 0.19 & -0.006 & 0.952 \\
3 & Distance & 86.25 & 24.78 & 0.245 & $0.014^{*}$ \\
4 & Center of Gravity & 44.12 & 14.76 & -0.270 & $0.007^{\star *}$ \\
\hline
\end{tabular}

Note: IQR = Inter Quartile Rang. ${ }^{\star}$ Denotes significant relationship at 0.05 level of significance. ${ }^{*}$ Denotes significant relationship at 0.01 level of significance

toe-touch skill among male kabaddi players (raiders). Five anthropometric variables: foot length, upper leg length, lower leg length, calf girth and three linear kinematical variables: speed, distance and center of gravity were taken in this study.

The result showed that there was an insignificant relationship ( $\mathrm{rs}=-0.17, \mathrm{p}=0.863$ ) between foot length variable and TTSP. The result of this finding is supported by the study conducted by Pandey and Reddy (2019) where they found that anthropometric variable foot length has no significant correlation with the performance of Forehand Overhead stroke i.e., clear, smash and drop in a Badminton (Pandey \& Reddy, 2019).

The results showed that there was an insignificant relationship ( $r s=0.048, p=0.634$ ) between upper leg length variable and TTSP. The results also showed that there was an insignificant relationship ( $r s=-0.90, p=0.373$ ) between lower leg length variable and TTSP. The results of these findings are supported by the study conducted by Yallappa (2020) and Sharma (2019) where they found that there was no significant relationship of no relationship of leg length with the kabaddi playing ability among university male kabaddi players and no significant relationship of shot-put performance with upper leg length and lower leg length (Yallappa, 2020; Sharma, 2019).

The result showed that there was an insignificant relationship ( $r s=0.093, p=0.355$ ) between calf girth variable and TTSP. The result of this finding is supported by the study conducted by Arshaq \& Martin (2018) where they found that there was an insignificant correlation between calf girth and performance of kho-kho game (Arshaq \& Martin, 2018).

The result showed that there was a significant relationship ( $r s=0.230, p=0.022$ ) between thigh girth variable and TTSP. The result of this finding is supported by the study conducted by Johnson (2016) and Madegowda \& Venkatesh (2016) where they found significant relationship between thigh girth and playing ability among kabaddi players (Johnson, 2016, Madegowda \& Venkatesh, 2016).
The result showed that there was an insignificant relationship ( $r s=-0.006, p=0.952$ ) between time variable and TTSP. The result of this finding is partially supported by the study conducted by Hart et al. (2016) who found that there was an in significant relationship of foot velocity with the kicking accuracy in football (Hart, Nimphius, Spiteri, Cochrane \& Newton, 2016).

The result showed that there was a significant relationship ( $r s=0.245, p=0.014$ ) between distance variable and TTSP. The result of this finding is supported by the study conducted by Landers et al. (2011) where they found that there was significant relationship of stride length with running and triathlon performance (Landers, Blanksby \& Rackland, 2011).

The result showed that there was a significant relationship ( $r s=-0.270, p=0.007$ ) between center of gravity variable and TTSP. The result of this finding is supported by the study conducted by Bal et al. (2009) who found that there was a significant relationship of center of gravity at the releasing moment of lay-up shot in basketball (Bal, Deol \& Kaur, 2009).

In case of anthropometrical variables, the results of this study are contradictory as compared to previous studies. Previous studies conducted in kabaddi shows relationship between anthropometric variables and playing ability of kabaddi players (Devaraju K., Needhiraja, 2012; Johnson, 2016, Madegowda \& Venkatesh, 2016). The reason behind these differences can be that in previous studies overall performance of players was measured. Players were allowed to perform any skill and there was not any specificity regarding the skill. But this study was focused only on performance of a single raiding skill: toe-touch.

In case of linear kinematical variables, there are not previous studies available in the literature in kabaddi. But, on the basis of experience of the researcher being a kabaddi player, it can be said that by increasing in distance between both feet during the execution phase of toe-touch skill can 
increase the chances to touch an opponent by foot for which this skill is performed during the raid. Lowered center of gravity provides better stability to perform movement smoothly. In case of toe-touch skill performance, if raider lowers down his center of gravity during the raid while performing toe-touch skill, then he can get more stability to perform skill smoothly.

\section{Conclusion}

The study concludes that increase in the size of thigh girth and distance positively contributes in toe-touch skill performance in kabaddi. Center of gravity negatively contributes in toe-touch skill performance in kabaddi. It can help coaches while make training plan for raiders to enhance their raiding performance.

\section{Acknowledgement}

The authors want to acknowledge Dr. Hemantajit Gogoi and Mr. Rohit Kumar Thapa for their help in a selection of statistical tests.

\section{References}

Jadhav, S.L. (2012). A study of role of yoga in kabaddi sport in India. World Research Journal of Physical Education and Sport Science, 1(1), 4-6.

Dey, S. K., Khanna, G. L., \& Batra, M. (1993). Morphological and physiological studies on Indian national kabaddi players. British Journal of Sports Medicine, 27(4), 237-242. https://doi.org/10.1136/bjsm.27.4.237

Arshaq, C.K., Martin, M. (2018). Relationship of selected anthropometrical and motor fitness variables to performance of kho-kho players. Indian Journal of Physical Education, Sports Medicine \& Exercise Science, 18(2), 18-20.

Nataraj, H.V., Chandrakumar, M. (2008). Motor ability variables as predictors of performance of kabaddi. Journal of Sports Science, 31(3), 12-18.

Patel, S., Pandey, U., Saxena, S., \& Kalyanpur, K. (2011). Comparative study of mental toughness among kabaddi players of different level. Indian Journal of Applied Research, 1(3), 201-202.

Itoo, M.A., Jain, R. (2020). The effect of clay and mat surface on coordinative and skill ability of the kabaddi players. International of Physical Education, Sports and Health, 7(5), 214-219.

Bosco, C., Komi, P. V., Tihanyi, J., Fekete, G., \& Apor, P. (1983). Mechanical power test and fiber composition of human leg extensor muscles. European Journal of Applied Physiology and Occupational Physiology, 51(1), 129-135. https://doi.org/10.1007/BF00952545

Campo, S. S., Vaeyens, R., Philippaerts, R. M., Redondo, J. C., de Benito, A. M., \& Cuadrado, G. (2009). Effects of LowerLimb Plyometric Training on Body Composition, Explosive Strength, and Kicking Speed in Female Soccer Players. Journal of Strength and Conditioning Research, 23(6), 17141722. https://doi.org/10.1519/JSC.0b013e3181b3f537

Gaurav, V. (2011). A comparative study of somatic traits and body composition between volleyball players and controls. Indian Journal of Science and Technology, 4(2), 116-118. https://doi.org/10.17485/ijst/2011/v4i2.11

Clarke, H., Harrison, Clarke-David, H. (1972). Advanced Statistical with Application to Physical Education. New Jersey: Prentice Hall.

Heyward, V.H. (2006). Advanced fitness assessment and exercise prescription. (5 ${ }^{\text {th }}$ ed.). Champaign, IL: Human Kinetics.

Keogh, J. (1999). The use of physical fitness scores and anthropometric data to predict selection in an elite under 18 Australian rules football team. Journal of Science and Medicine in Sport, 2(2), 125-133. https://doi.org/10.1016/S1440-2440(99)80192-3

Viswanathan, J., Chandrasekaran, K. (2011). Optimizing positionwise anthropometric models for prediction of playing ability among elite Indian basketball players. International Journal of Sports Science and Engineering, 5(2), 67-76.

Wilmore, J.H., Costill, D.L. (2005). Physiology of sport and exercise. Human Kinetics, Champaign, IL; (2015).

Hatze, H. (1981). A comprehensive model for human motion simulation and its application to the take-off phase of the long jump. Journal of Biomechanics, 14(3), 135-142. https://doi.org/10.1016/0021-9290(81)90019-1

Bartlett, R. (2007). Introduction to Sports Biomechanics: Analysing Human Movement Patterns. E\&FN Spon.

Devaraju, K., \& Kalidasan, R. (2012). Prediction of Kabaddi Playing Ability from Selected Anthropometrical and Physical Variables among College Level Players. Asian Journal of Information Technology, 11(4), 131-134. https://doi.org/10.3923/ajit.2012.131.134

Johnson, P. (2016). Predominance of selected anthropometric measurements on kabaddi playing ability among college male students. Editorial Board, 15(1), 76-79.

Pandey. S.S.A.K., Sardar, S. (2016). An estimation of kabaddi performance on the basis of selected physical fitness components. Indian Journal of Physical Education, Sports and Applied Sciences, 6(4), 27-35.

Ram, J. (2019a). Comparative study of angular kinematical variables during running hand touch skill among different level kabaddi players. International Journal of Yogic. Human Movement and Sports Sciences, 4(1), 1388-1389.

Ram, J. (2019b). Comparative study of linear kinematical variables during running hand touch skill among different level kabaddi players. International Journal of Physiology, Nutrition and Physical Education, 4(1), 22072208.

Norton, K., \& Olds, T. (2006). A Textbook of Body Measurement for Sports and Health Education: Anthropometrica. CBS Publishers \& Distributors.

Gogoi, H., Rajpoot, Y.S. (2019). Test-retest reliability of kinovea software. Online International Interdisciplinary Research Journal, 9(4), 184-189.

Kvålseth, T. O. (1989). Note on Cohen's Kappa. Psychological Reports, 65(1), 223-226. https://doi.org/10.2466/pr0.1989.65.1.223

Zar, J. H. (2005). Spearman Rank Correlation. In P. Armitage \& T. Colton (Eds.), Encyclopedia of Biostatistics (p. b2a15150). John Wiley \& Sons, Ltd. https://doi.org/10.1002/0470011815.b2a15150 
Pandey, B.M., Reddy, T.O. (2019). Relationship of anthropometric measurements with the performance of forehand overhead stroke in badminton. International Journal of Physiology, Nutrition and Physical Education, 4(1), 481-483

Yallappa, M. (2020). Relationship of selected physical, anthropometrical and physiological parameters to performance of university male kabaddi players. Journal of Sports Science and Nutrition, 1(2), 01-04.

Sharma, M. (2019). Study of some anthropometric and motor performance variables in the performance of shot put in university players. International Journal of Yogic, Human Movement and Sports Sciences, 4(2), 21-22.

Johnson, P. (2016). Predominance of selected anthropometric measurements on kabaddi playing ability among college male students. Editorial Board, 15(1), 76-79.
Madegowda, T.B., Venkatesh, C. (2016). The relationship of selected morphological variables to performance of subjunior national male Kabaddi Players. International Journal of Physical Education, Sports and Health, 3(3), 434-436.

Hart, N. H., Nimphius, S., Cochrane, J. L., \& Newton, R. U. (2013). Leg mass characteristics of accurate and inaccurate kickers - an Australian football perspective. Journal of Sports Sciences, 31(15), 1647-1655. https://doi.org/10.1080/02640414.2013.793377

Landers, G. J., Blanksby, B. A., \& Rackland, T. (2011). Cadence, stride rate and stride length during triathlon competition. International Journal of exercise science, 4(1), 40.

Bal, B. S., Deol, N. S., \& Kaur, P. J. (2009). Relationship Of Kinematic Variables with the performance of basketball players in lay-up shot. Journal of Physical Education and Sport, 24(3), 1-7.

\title{
ЗВ'ЯЗОК МІЖ ВИБРАНИМИ АНТРОПОМЕТРИЧНИМИ Й ЛІНІЙНИМИ КІНЕМАТИЧНИМИ ЗМІННИМИ ТА ВИКОНАННЯМ ДОТИКУ ПАЛЬЦЕМ НОГИ В КАБАДДІ
}

\author{
Джасвір Рам ${ }^{1 \mathrm{ABCDE}}$, Джозеф Сінгх ${ }^{1 \mathrm{ADE}}$ \\ ${ }^{1}$ Національний інститут фізичного виховання імені Лакшмі Бай \\ Авторський вклад: А - дизайн дослідження; В - збір даних; C - статаналіз; D - підготовка рукопису; Е - збір коштів \\ Реферат. Стаття: 6 с., 5 табл., 2 рис., 33 джерела.
}

Мета дослідження - виявити зв'язок між вибраними антропометричними й лінійними кінематичними змінними та виконанням дотику пальцем ноги у чоловіків-гравців кабадді (рейдерів).

Матеріали і методи. Для дослідження було відібрано сто чоловіків-рейдерів. Вік випробовуваних коливався від 18 до 25 років. Вибрані антропометричні показники: довжина стопи, довжина стегна, довжина гомілки, обхват стегна та обхват ікри були виміряні за допомогою стандартного обладнання. Вибрані лінійні кінематичні змінні вимірювалися з використанням цифрового програмного забезпеченням "Kinovea version-0.9.3". Виконання дотику пальцем ноги рейдерами оцінювалося трьома експертами. Надійність рейтингових оцінок, нарахованих експертами випробовуваним, було перевірено за допомогою тесту Каппа Коена, коефіцієнт Каппа визнано достовірним.
Результати. Рангова кореляція Спірмена показала, що існує значна кореляція змінних обхвату стегна $(\mathrm{rs}=0,230, \mathrm{p}=0,022)$, відстані $(\mathrm{rs}=0,245, \mathrm{p}=0,014)$ та центру ваги (rs $=-0,270, p=0,007)$, і не має значної кореляції змінних довжини стегна ( $\mathrm{rs}=0,048, \mathrm{p}=0,634)$, довжини гомілки ( $\mathrm{rs}=-0,90, \mathrm{p}=0,373)$, обхвату ікри ( $\mathrm{rs}=0,093$, $\mathrm{p}=0,355)$, довжини стопи ( $\mathrm{rs}=-0,17, \mathrm{p}=0,863$ ) та часу (rs $=-0,006, p=0,952)$ з виконанням дотику пальцем ноги в кабадді.

Висновки. У дослідженні зроблено висновок, що на виконання дотику пальцем ноги у чоловіків-гравців кабадді обхват стегна і відстань впливають позитивно, а центр ваги - негативно.

Ключові слова: кабадді, рейдер, навичка, антропометричні змінні, лінійна кінематика.

\section{Information about the authors:}

Ram Jasvir: jasvirram9@gmail.com; http://orcid.org/0000-0002-4626-2239; Lakshmibai National Institute of Physical Education, Gwalior, 474002, India.

Singh Joseph: josephsingh.2035@gmail.com; https://orcid.org/0000-0003-4906-688X; Lakshmibai National Institute of Physical Education, Gwalior, 474002, India.

Cite this article as: Ram, J., \& Singh, J. (2021). Relationship of Selected Anthropometric and Linear Kinematical Variables with the Performance of Toe-Touch Skill in Kabaddi. Teoriâ ta Metodika Fizičnogo Vihovannâ, 21(4), 304-309.

https://doi.org/10.17309/tmfv.2021.4.03

Received: 12.09.2021. Accepted: 16.10.2021. Published: 25.12.2021

This work is licensed under a Creative Commons Attribution 4.0 International License (http://creativecommons.org/licenses/by/4.0). 